\title{
A regulatory effect of IL-21 on T follicular helper-like cell and B cell in rheumatoid arthritis
}

Rui Liu', Qian Wu², Dinglei Su', Nan Che ${ }^{1}$, Haifeng Chen², Linyu Geng ${ }^{2}$, Jinyun Chen², Wanjun Chen ${ }^{3}$, Xia Li $i^{1,4^{*+}}$ and Lingyun Sun ${ }^{1 *+}$

\begin{abstract}
Introduction: Interleukin (IL)-21 is a member of type I cytokine family. Recent studies indicate that IL-21 can promote $T$ follicular helper (Tfh) cell differentiation and survival, a specialized T cell subset which provides help for B cell. It can also regulate the activation, proliferation and differentiation of human B cell and immunoglobulin (lg) production as well as isotype switching of plasma cell. Rheumatoid arthritis (RA) is characterized by auto-antibodies overproduction such as rheumatoid factor (RF) and anti-cyclic citrullinated peptide (anti-CCP) antibody, suggesting a pivotal role of Tfh cell and B cell in the pathogenesis of RA. This study aimed to investigate whether IL-21 had a regulatory effect on Tfh cell and B cell in RA.
\end{abstract}

Methods: Serum IL-21 concentrations were measured by ELISA. The correlations between serum IL-21 levels and clinical features of RA patients were analyzed by Spearman's rank test. The percentages of Tfh-like cells, IL-21 receptor (R) expression on Tfh-like cells and B cells in peripheral blood (PB) were analyzed by flow cytometry. Peripheral blood mononuclear cells (PBMC) were stimulated by $\mathrm{rlL}-21(100 \mathrm{ng} / \mathrm{ml})$ in the presence or absence of anti-CD40 and/or anti-IgM, and changes of IL-21R, activation-associated surface markers (CD25, CD69 and CD40), the proliferation, apoptosis and differentiation of B cells were analyzed by flow cytometry. Production of IgG and $\lg M$ in the culture supernatants was determined by ELISA.

Results: The results showed that the serum IL-21 levels in RA patients were significantly higher than that of healthy controls (HC). IL-21 concentrations were positively correlated with 28-joint count disease activity score (DAS28) and anti-CCP antibody in RA patients with high IL-21 levels. Furthermore, the frequencies of peripheral CXCR5 ${ }^{+}$PD $-1^{+} C D 4^{+}$Tfh-like cells markedly increased in RA patients and the percentages of Tfh-like cells were positively correlated with DAS28 and anti-CCP antibody levels. Moreover, elevated IL-21 levels were also correlated with the frequencies of Tfh-like cells. IL-21R expression on both Tfh-like cells and B cells were significantly enhanced in RA patients. In cultures vitro, exogenous IL-21 upregulated IL-21R expression and activation-associated surface markers on B cells and promoted more B cell proliferation in RA than in HC. This IL-21-mediated effect could be reversed by IL-21R-specific neutralizing antibody. Importantly, IL-21 promoted more differentiation of B cell into plasmablast and higher levels of IgG and IgM production in RA than in HC.

Conclusions: Increased serum IL-21 levels in RA patients correlate with DAS28, anti-CCP antibody and frequencies of Tfh-like cells. IL-21 supports B cell activation, proliferation and antibody secretion via IL-21R pathway. Thus, IL-21 may be involved in the pathogenesis of RA and antagonizing IL-21 could be a novel strategy for the therapy of RA.

\footnotetext{
*Correspondence: lixia416@yahoo.com.cn; Lingyunsun2001@yahoo.com.cn

+ Contributed equally

'Department of Immunology and Rheumatology, Drum Tower Clinical

Medical College of Nanjing Medical University, Nanjing, Jiangsu, 210008, PR

China

Full list of author information is available at the end of the article
} 


\section{Introduction}

Interleukin (IL)-21 is a member of the type I cytokine family and can be secreted by $\mathrm{CD} 4^{+} \mathrm{T}$ cells including $\mathrm{T}$ follicular helper (Tfh) cells, Th17 cells and natural killer (NK) T cells [1]. IL-21 signals through the common cytokine receptor $\gamma$ chain in combination with its functional receptor, IL-21 receptor ( $R$ ) which is mainly expressed on B cells and also on T cells, NK cells, dendritic cells, epithelial cells and fibroblasts [2-4].

It has been reported that IL-21 is able to enhance the proliferation and effector characteristics of activated $\mathrm{CD}^{+}$and $\mathrm{CD} 8^{+} \mathrm{T}$ cells [5] and limit the differentiation of inducible regulatory T cells [6-8]. IL-21 can also modulate $\mathrm{Tfh}$ cell differentiation via the upregulation of Bcl-6, the transcription factor of Tfh cells [9]. The Tfh cell is a specialized $\mathrm{T}$ cell subset, which is characterized by increased expression of molecules, including CXCR5, PD-1, ICOS, CD40L and IL-21 and decreased expression of CCR7 [10]. Expressing these molecules allows Tfh cell migration into the germinal center (GC) to provide help for $B$ cell growth, differentiation and class switching [11-13]. Reportedly, exposure of CD4 ${ }^{+} \mathrm{T}$ cells to IL-21 drives them to differentiate into a Tfh cell subset partly through modulation of the expression of CXCR 5 and CCR7 by IL-21 in an autocrine manner [14,15]. Also, Tfh cell regulation of $\mathrm{B}$ cell proliferation, differentiation and antibody production is via the secretion of IL-21 [16-18].

Moreover, IL-21 can directly act on B cells. IL-21 costimulation is capable of promoting plasma cells differentiation from $\mathrm{CD} 27^{+}$memory B cells, inducing class switch recombination and stimulating poorly responsive naive cord blood B cells into IgG-secreting plasma cells in humans [11]. In addition, antigen-specific memory B cells and plasma cells fail to expand and IgG production is significantly impaired following secondary immunization of IL-21R.KO mice [19]. Furthermore, IL-21 acts in a B cell-intrinsic fashion to control GC formation [9]. The absence of IL-21 signaling profoundly affects GC persistence and function, influencing its proliferation, transition into memory $B$ cells, and affinity maturation [20]. Thus, the effect of IL-21 on B cells may contribute to the development of autoimmune diseases.

Rheumatoid arthritis (RA) is characterized by persistent synovitis and systemic inflammation, frequently leading to cartilage and bone destruction. Although the etiology and pathology remain elusive, auto-antibodies to citrullinated cyclic peptides (CCP) and rheumatoid factor (RF) have been indicated to be associated with the disease course [21-25]. When transferring auto-antibodies to mice with certain genetic backgrounds, they may provoke articular inflammation [26,27]. Importantly, B cells are the primary source of RF and anti-CCP auto-antibodies and Tfh cells assist B cells, suggesting a critical role of
Tfh and B cells in the pathogenesis of RA. Recent studies observe that IL-21R transcript is expressed by synovial macrophages and fibroblasts from RA patients but not from patients with osteoarthritis (OA) [28] and IL-21R deficiency in the $\mathrm{K} / \mathrm{BxN}$ mouse model of inflammatory arthritis is sufficient to protect it from arthritis [29]. However, the effect of IL- 21 regulation on Tfh and B cells in the pathogenesis of RA remains largely unknown.

In this report, we investigated the function of IL-21 on Tfh-like cells and B cells in RA. Our data showed that increased serum IL-21 levels in RA patients correlated positively with 28 -joint count disease activity score (DAS28), serum anti-CCP antibodies and frequencies of Tfh-like cells. IL-21 supported B cell activation, proliferation and antibody secretion. Strikingly, blockade of IL21R markedly inhibited the impact of IL-21 on B cells in RA patients.

\section{Materials and methods}

\section{Patients and controls}

Serum samples were collected from active RA patients $(n=120)$ admitted to the ward of The Affiliated Drum Tower Hospital of Nanjing Medical University, from July 2010 to September 2012. All patients fulfilled the American College of Rheumatology criteria for the classification of RA and they had no other autoimmune or systemic diseases. None of these patients was pregnant or menopausal at the time of the study. Age- and sexmatched healthy controls ( $\mathrm{HC}, n=80)$ were obtained from the medical examination center. Serum samples were stored at $-80^{\circ} \mathrm{C}$ until used. The study protocol was approved by the ethics committee of The Affiliated Drum Tower Hospital of Nanjing Medical University. Written informed consents were obtained from all patients and controls. Detailed clinical characteristics and laboratory features are shown in Table 1.

\section{Enzyme-linked immunosorbent assay (ELISA) for serum IL- 21 levels}

Serum IL-21 levels in RA patients and HC were measured by human IL-21 ELISA kits (Biolegend, San Diego, CA, USA) according to the instructions of the manufacturer. The plate was read at $450 \mathrm{~nm}$ and sensitivity of the ELISA kits used in the experiment was $16 \mathrm{pg} / \mathrm{ml}$.

\section{Clinical data and inflammation index analysis}

All patients were followed up to obtain clinical data on age, sex, disease duration, number of swollen and tender joints, erythrocyte sedimentation rate (ESR), C-reactive protein (CRP), anti-CCP antibodies, RF-IgM, RF-IgG and RF-IgA.

$>$ ESR was evaluated by the Westergren method. Values $\leq 15 \mathrm{~mm} / \mathrm{h}$ for men and $20 \mathrm{~mm} / \mathrm{h}$ for women were 
Table 1 Clinical and laboratory features in 120 patients with rheumatoid arthritis (RA)

\begin{tabular}{lc}
\hline Characteristics & Values \\
\hline Age, yrs & $58.95 \pm 1.12$ \\
Men/women & $33 / 87$ \\
Disease duration, yrs & $18.02 \pm 8.98$ \\
DAS28 & $4.89 \pm 0.09$ \\
ESR, mm/h & $60.86 \pm 2.60$ \\
CRP, mg/l & $38.71 \pm 4.03$ \\
RF-IgM-positive & $89(74.17)$ \\
RF-IgG-positive & $66(55.00)$ \\
RF-IgA-positive & $72(60.00)$ \\
Anti-CCP-positive & $65(54.17)$ \\
Treatment & \\
DMARDs & $9(7.50)$ \\
CS & $22(18.33)$ \\
CS+DMARDs & $41(34.17)$ \\
Others & $48(40.00)$ \\
\hline
\end{tabular}

Clinical characteristics are presented as mean \pm SEM or number (\%). DAS28, 28-joint count disease activity score; ESR, erythrocyte sedimentation rate; CRP, C-reactive protein; RF, rheumatoid factor; Anti-CCP, anti-cyclic citrullinated peptide antibody; CS, corticosteroid; DMARDs, disease-modifying antirheumatic drugs; Others, non-steroidal anti-inflammatory drugs, traditional Chinese medicine or never taking any medication.

considered normal. CRP was examined by the immunonephelometry method and a value $>8 \mathrm{mg} / \mathrm{l}$ was considered positive. Anti-CCP antibody, RF-IgM, RF-IgG and RF-IgA were tested by ELISA, with normal ranges of 0 to $5 \mathrm{RU} / \mathrm{ml}$ for RF-IgM, and 0 to $20 \mathrm{RU} / \mathrm{ml}$ for RF-IgG and RF-IgA. The DAS28 was calculated as previously described [30].

\section{Detection of IL-21R and activation marker expression by flow cytometry}

Peripheral blood mononuclear cells (PBMC) were isolated from active RA patients or $\mathrm{HC}$ using Ficoll density-gradient centrifugation. The cell suspension was washed three times in phosphate- buffered saline (PBS) and then labeled with the following monoclonal antibodies: phycoerythrin (PE)-conjugated anti-IL21R (R\&D Systems, Minneapolis, MN, USA), fluorescein isothiocyanate (FITC)- or allophycocyanin (APC)-conjugated anti-CD19, Pecy7-conjugated anti-CD40, PE-conjugated anti-CD25, FITC-conjugated anti-CD69, FITC-conjugated anti-CD4, APC-conjugated anti-CXCR5 and PerCP-Cy5.5-conjugated anti-PD-1 (BD Biosciences, Franklin Lakes, NJ, USA). For surface marker staining, cells were maintained in the dark at $4^{\circ} \mathrm{C}$ for 30 minutes and then washed twice in PBS. IL-21R on Tfhlike cells and B cells and activation surface markers expression of B cells were analyzed by flow cytometry.

\section{B cell stimulation by IL-21}

PBMC from RA patients or HC were cultured in RPMI 1640 supplemented with $10 \%$ fetal calf serum (FCS) and antibiotics (penicillin $100 \mathrm{IU} / \mathrm{ml}$, streptomycin $100 \mu \mathrm{g} / \mathrm{ml}$; Invitrogen, Camarillo, CA, USA) in a humidified atmosphere of $5 \% \mathrm{CO}_{2}$ at $37^{\circ} \mathrm{C}$. For the studies of IL-21R and $\mathrm{B}$ cell activation, PBMC $\left(1 * 10^{6} /\right.$ well) were added to 96-well plates directly with or without $100 \mathrm{ng} / \mathrm{ml} \mathrm{recombi-}$ nant human IL-21 (Abcam, Cambridge, MA, USA). For proliferation studies, PBMC $\left(1 * 10^{6} /\right.$ well $)$ were treated with $3 \mu \mathrm{g} / \mathrm{ml}$ anti-CD40 antibody (eBioscience, San Diego, CA, USA), 50 ng/ml rIL-4 (PeproTech Inc, Rocky Hill, NJ, USA) and $100 \mathrm{ng} / \mathrm{ml} \mathrm{rIL-21} \mathrm{(Abcam).} \mathrm{For} \mathrm{apoptosis} \mathrm{stu-}$ dies, PBMC $\left(1 * 10^{6} /\right.$ well $)$ were stimulated with $3 \mu \mathrm{g} / \mathrm{ml}$ anti-CD40 antibody (eBioscience), and $100 \mathrm{ng} / \mathrm{ml} \mathrm{rIL-21}$ (Abcam). For differentiation to plasmablast studies, PBMC (1*10 $10^{6}$ well) were treated with $3 \mu \mathrm{g} / \mathrm{ml}$ anti-CD40 antibody (eBioscience), $5 \mu \mathrm{g} / \mathrm{ml} \mathrm{F}(\mathrm{ab}) 2$ goat anti-human IgM (Jackson ImmunoResearch, West Grove, PA, USA) and $100 \mathrm{ng} / \mathrm{ml} \mathrm{rIL-21}$ (Abcam). To investigate the possible mechanism of IL-21, $10 \mathrm{ug} / \mathrm{ml}$ anti-IL-21R antibody (Biolegend) was included in cell cultures.

\section{Quantification of cytokines in serum}

Serum cytokines were analyzed using Quantibody Human TH17 Array 1 (QAH-TH17-1, RayBiotech, Norcross, GA, USA), according to the manufacturer's specification. Each sample was prepared in triplicate. An Axon scanner 4000B with GenePix software was used to collect fluorescence intensities.

\section{Proliferation and apoptosis assays}

PBMC from RA patients and $\mathrm{HC}$ were labeled with $5 \mu \mathrm{M}$ carboxyfluorescein diacetate succinimidyl ester (CFSE) (Invitrogen) in PBS for 10 minutes at $37^{\circ} \mathrm{C}$. An excess of ice-cold RPMI 1640 with 10\% FCS was added to the cells to quench the reaction and cells were washed extensively. CFSE-labeled cells ( $1 * 10^{6} /$ well) were cultured according to above-mentioned methods. Following 4 days of culture, cells were collected and then stained with APC-conjugated anti-CD19 (BD Biosciences). B cell proliferation was determined by flow cytometry analysis of CFSE fluorescence intensity. To detect apoptotic cells, cultured PBMC were collected and resuspended in $100 \mu \mathrm{l}$ of $1 \times$ binding buffer (10 mM HEPES (pH 7.4), $140 \mathrm{mM} \mathrm{NaCl}$ and $2.5 \mathrm{mM} \mathrm{CaCl}_{2}$ ) and stained with $5 \mu \mathrm{l}$ of FITC-conjugated Annexin V (BD PharMingen, San Diego, CA, USA) for 15 minutes at room temperature in the dark and then analyzed by flow cytometry.

\section{Determination of immunoglobin (lg) levels}

After 4 days' culture, secreted IgG and IgM in the culture supernatants were quantitated by ELISA (MABTECH, Nacka Strand, Sweden) according to the instructions of the manufacturer. PE-conjugated anti-CD138 (BD Biosciences) expression was analyzed in cultured cells using flow cytometry. 


\section{Statistical analysis}

Data were summarized as means \pm standard error of the mean (SEM). Statistical significance was performed by Student's $t$-test and the correlation coefficient between serum IL-21 levels and clinical features in RA patients were analyzed by Spearman's rank test. All statistical analyses were performed using GraphPad Prism software (Graph-Pad, San Diego, CA, USA). A $P$-value $<0.05$ was considered significantly different.

\section{Results}

Positive correlation of increased IL-21 with disease activity and auto-antibody production in RA patients

We measured the serum IL-21 levels in RA patients $(n=$ $120)$ and age-matched $\mathrm{HC}(n=80)$ by ELISA and revealed that RA patients had significantly higher IL-21 levels than HC subjects $(197.60 \pm 32.57$ vs. $59.10 \pm 3.45 \mathrm{pg} / \mathrm{ml}, P<$ 0.01 ; Figure 1a).

Then the correlations of IL-21 concentrations with clinical activity and auto-antibody levels were analyzed in the high IL-21 group. IL-21 concentrations > $120.74 \mathrm{pg} / \mathrm{ml}$ (mean $+2 \mathrm{SD}$ of the HC group) were defined as high IL21. We found that RA patients with elevated IL-21 levels had a higher DAS28 $(r=0.44, P=0.006$; Figure $1 b)$. In addition, high IL-21 levels were positively correlated with anti-CCP antibody levels ( $r=0.36, P=0.02$; Figure $1 \mathrm{c})$, but not with the levels of RF-IgM $(r=0.24, P=0.11)$, RFIgG $(r=0.31, P=0.06)$ and RF-IgA $(r=0.17, P=0.29$; Figure 1d).

As IL-21 was related to disease activity, we assessed whether drug treatment had any influence on the concentrations of IL-21. RA patients were divided into four groups: 1) patients taking disease modifying anti-rheumatic drugs (DMARDs) including a single DMARD and combination DMARDs; 2) patients taking corticosteroid (CS) including a single CS and CS plus non-DMARDs; 3) patients taking CS plus DMARDs, and 4) patients taking other treatments, including non-steroidal anti-inflammatory drugs (NSAIDs), traditional Chinese medicine, and patients never taking any medication. As expected, IL-21 levels were lowest in patients treated with CS plus DMARDs (133.50 \pm $18.22 \mathrm{pg} / \mathrm{ml}$; Figure 1e) and the highest levels of IL-21 were observed in group 4) who were not receiving CS or DMARDs $(270.60 \pm 71.93 \mathrm{pg} / \mathrm{ml}$; Figure 1e), although this was not statistically significant.

Positive correlation of increased Tfh-like cells with disease activity and auto-antibody production in RA patients

Recent studies found that Tfh cells could provide help for $B$ cells and allow formation of long-lived antibody responses $[10,17,31]$. First, the frequencies of circulating CXCR $5^{+} \mathrm{PD}-1^{+} \mathrm{CD} 4^{+}$Tfh-like cells were examined. As shown in Figure 2a, the frequencies of circulating Tfh-like cells were significantly upregulated in peripheral blood
(PB) of RA patients $(5.71 \% \pm 0.53 \%$ vs. $2.32 \% \pm 0.13 \%, P<$ 0.01; Figure 2a). Serum IL-21 levels in these subjects are shown in Additional file 1a. Furthermore, the correlations of high proportions of Tfh-like cells in RA patients, with clinical activity and auto-antibody production were analyzed. The frequencies of Tfh-like cells $>4.12 \%$ (mean + 2SD of the HC group) were defined as high proportions of Tfh-like cells. We found that patients with upregulated frequencies of Tfh-like cells had a higher DAS28 $(r=0.39$, $P=0.02$; Figure $2 \mathrm{~b}$ ). In addition, the percentages of Tfhlike cells were positively correlated with anti-CCP antibodies $(r=0.36, P=0.04$; Figure $2 \mathrm{c})$, but not with RF-IgM $(r=0.10, P=0.58)$, RF-IgG $(r=0.33, P=0.06)$ and RFIgA $(r=0.12, P=0.51$; Figure $2 \mathrm{~d})$ among the RA patients with high frequency of Tfh-like cells.

\section{Positive correlation of increased IL-21 with the frequencies of Tfh-like cells in RA patients}

Because the source of IL-21 was Tfh cells, Th17 cells and NK T cells, we next investigated the correlation between IL-21 levels and the percentages of Tfh-like cells in the group of RA patients with high IL-21. We found that IL-21 levels positively correlated with the percentages of Tfh-like cells ( $r=0.49, P=0.04$; Figure $3 \mathrm{a}$ ). Flow cytometry analyses showed that IL-21 was derived from both $\mathrm{CXCR}^{+} \mathrm{CD}^{+}{ }^{+} \mathrm{T}$ cells and CXCR $5{ }^{-} \mathrm{CD} 4^{+} \mathrm{T}$ cells $(1.17 \% \pm$ $0.27 \%$ vs. $1.07 \% \pm 0.25 \%, P>0.05$; Figure $3 \mathrm{~b}$ ).

To investigate a direct function of IL-21 on Tfh-like cells in RA, we examined IL-21R expression on Tfh-like cells. IL-21R expression on Tfh-like cells in RA patients was substantially augmented compared to $\mathrm{HC}(6.64 \% \pm 0.97 \%$ vs. $3.03 \% \pm 0.40 \%, P<0.05$; Figure $3 \mathrm{c}$ ), but this phenomenon was not detected on CXCR $5^{-} \mathrm{CD} 4{ }^{+} \mathrm{T}$ cells $(0.62 \% \pm$ $0.11 \%$ vs. $1.00 \% \pm 0.19 \%, P>0.05$; Figure $3 d)$. Serum IL-21 levels of these subjects are shown in Additional file $1 \mathrm{~b}$. Given that IL-21R expression was significantly increased in PB of RA patients, we observed the functional relevance of IL-21 to IL-21R expression in RA. However, patients with elevated IL-21 levels did not have any relationship with IL-21R expression on Tfh-like cells ( $r=0.28, P=$ 0.29; Figure 3e). We then cultured PBMC with rIL-21 in vitro and IL-21R expression was determined. Figure $3 \mathrm{f}$ demonstrated that IL-21R expression on Tfh-like cells remained unchanged both in RA patients $(23.05 \% \pm 2.98 \%$ vs. $24.16 \% \pm 3.07 \%, P>0.05$; Figure $3 f)$ and in $\mathrm{HC}(17.36 \%$ $\pm 2.19 \%$ vs. $18.59 \% \pm 2.23 \%, P>0.05$; Figure 3 f). This is consistent with in vivo results. Serum IL-21 levels in these subjects are shown in Additional file 1c.

\section{The effect of IL-21 on B cell activation in RA patients}

First, we found that IL-21R expression was significantly upregulated on B cells in RA patients $(54.88 \% \pm 2.64 \%$ vs. $38.39 \% \pm 2.35 \%, P<0.01$; Figure $4 \mathrm{a}$ ). Serum IL-21 levels of these subjects are shown in Additional file 2a. Then we 

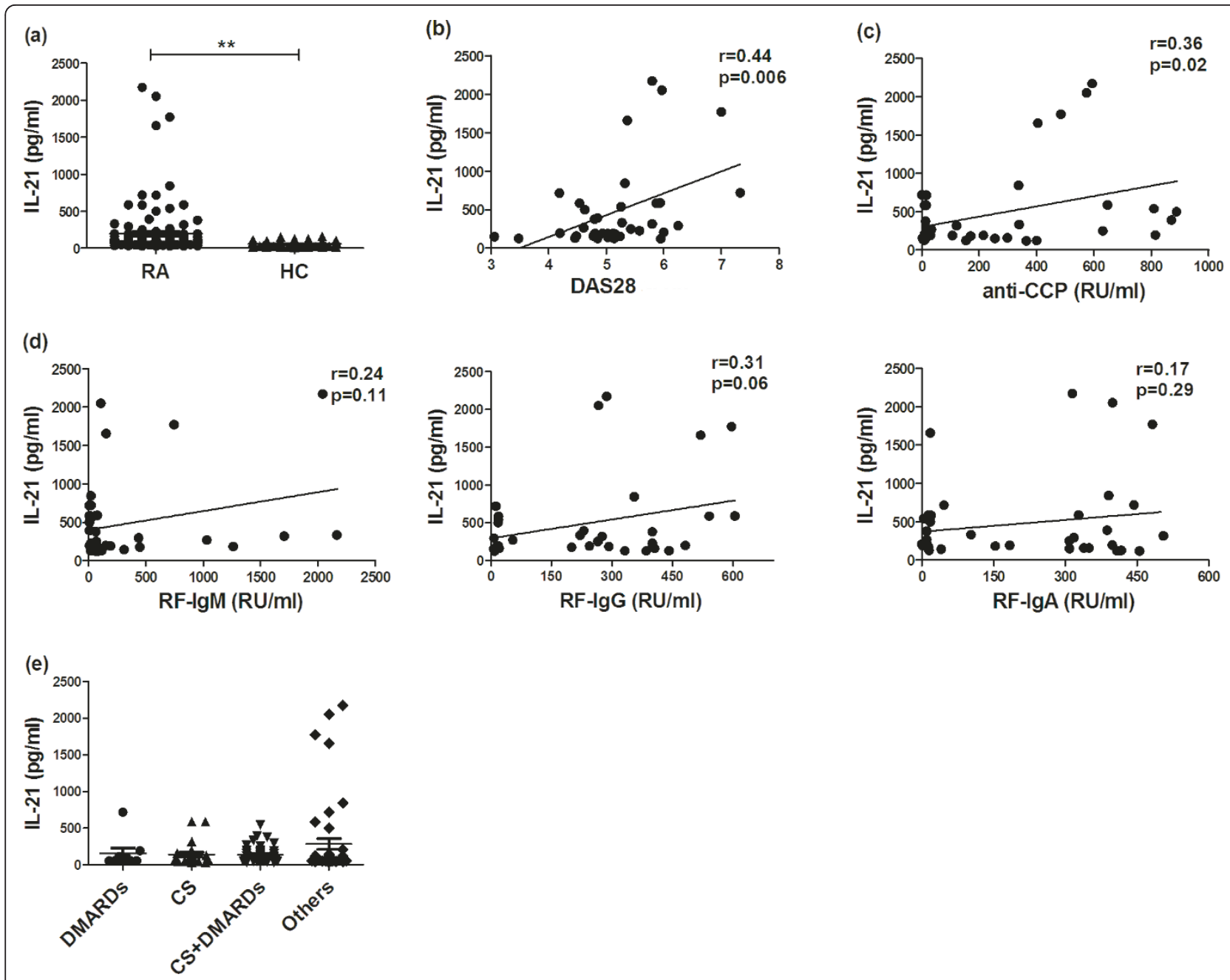

Figure 1 Positive correlation of high serum IL-21 levels with disease activity and auto-antibody production in patients with rheumatoid arthritis (RA). (a) Serum IL-21 levels of RA patients $(n=120)$ and healthy controls $(H C)(n=80)$ were measured by ELISA. (b) There was positive correlation between serum IL-21 and 28-joint count disease activity score (DAS28) in RA patients with high IL-21 ( $n=38)$. (c) There was a positive correlation between serum IL-21 and levels of anti-cyclic citrullinated peptide (anti-CCP) antibody in RA patients with high IL-21 ( $n=38$ ). (d) Serum IL-21 had no relationship with levels of rheumatoid factor (RF)-IgM, RF-lgG or RF-IgA in RA patients with high IL-21 ( $n=38$ ). (e) Serum IL-21 levels in RA patients treated with different drugs. ${ }^{* *} P<0.01 ;{ }^{*} P<0.05$. DMARDS, disease-modifying antirheumatic drugs; $C S$, corticosteroids.

cultured PBMC with rIL-21 in vitro and IL-21R expression was determined. Figure $4 \mathrm{~b}$ showed that IL-21R expression on B cells was significantly enhanced in response to rIL-21 in RA patients $(29.11 \% \pm 4.11 \%$ vs.38.13\% $\pm 4.72 \%, P<$ 0.05 ; Figure $4 \mathrm{~b})$ but not in $\mathrm{HC}(19.84 \% \pm 2.68 \%$ vs. $21.71 \%$ $\pm 2.95 \%, P>0.05)$. Serum IL-21 levels in these subjects were shown in Additional file $2 \mathrm{~b}$.

Next, we investigated whether IL-21 was able to regulate $\mathrm{B}$ cell activation. We first found that the expressions of $\mathrm{B}$ cell activation markers (CD25: $56.34 \% \pm 2.53 \%$ vs. $28.78 \%$ $\pm 2.29 \%, P<0.01$; CD69: $1.51 \% \pm 0.24 \%$ vs. $0.71 \% \pm 0.18 \%$, $P<0.05$; CD $40: 87.85 \% \pm 2.53 \%$ vs. $77.13 \% \pm 4.12 \%, P<$ 0.05 ; Figure $4 \mathrm{c}$ ) were significantly upregulated in RA patients, suggesting B cells are in an activated state in RA. Serum IL-21 levels in these subjects are shown in
Additional file 2c. Thus, we supposed that B cell activation was partly due to elevated IL-21 in RA. Then we cultured PBMC in the presence and absence of rIL-21 and the expressions of those markers on B cells were examined. As shown in Figure 4d, inclusion of rIL-21 led to higher expressions of CD25, CD69 and CD40 in RA patients and this response was reversed by anti-IL-21R antibodies (CD25: $43.48 \% \pm 2.63 \%$ vs. $61.63 \% \pm 2.63 \%$ vs. $57.74 \% \pm$ 2.89\%, $P<0.05$; CD69: $1.48 \% \pm 0.26 \%$ vs. $2.85 \% \pm 0.43 \%$ vs. $2.30 \% \pm 0.48 \%, P<0.05$; CD $40: 73.14 \% \pm 1.09 \%$ vs. $81.77 \% \pm 1.77 \%$ vs. $75.22 \% \pm 1.64 \%, P<0.05$; Figure $4 d)$. However, rIL-21 only slightly upregulated CD25 expression on B cells in $\mathrm{HC}$ and had no effect on the expression of CD69 and CD40 (CD25: $26.92 \% \pm 1.82 \%$ vs. $34.71 \% \pm$ $2.50 \%$ vs. $29.14 \% \pm 1.76 \%, P<0.05$; CD69: $0.73 \% \pm 0.23 \%$ 


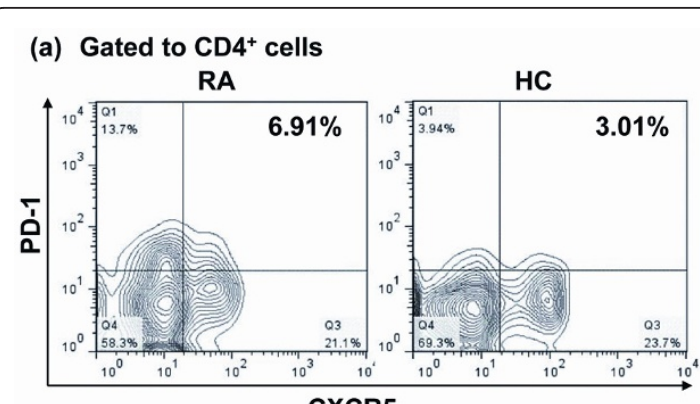

(b)

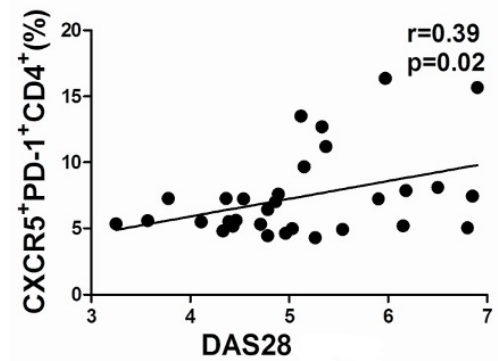

(d)

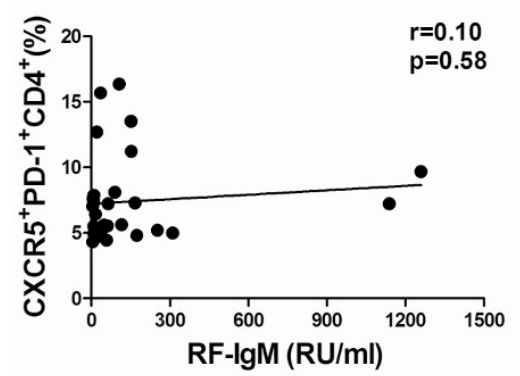

(c)
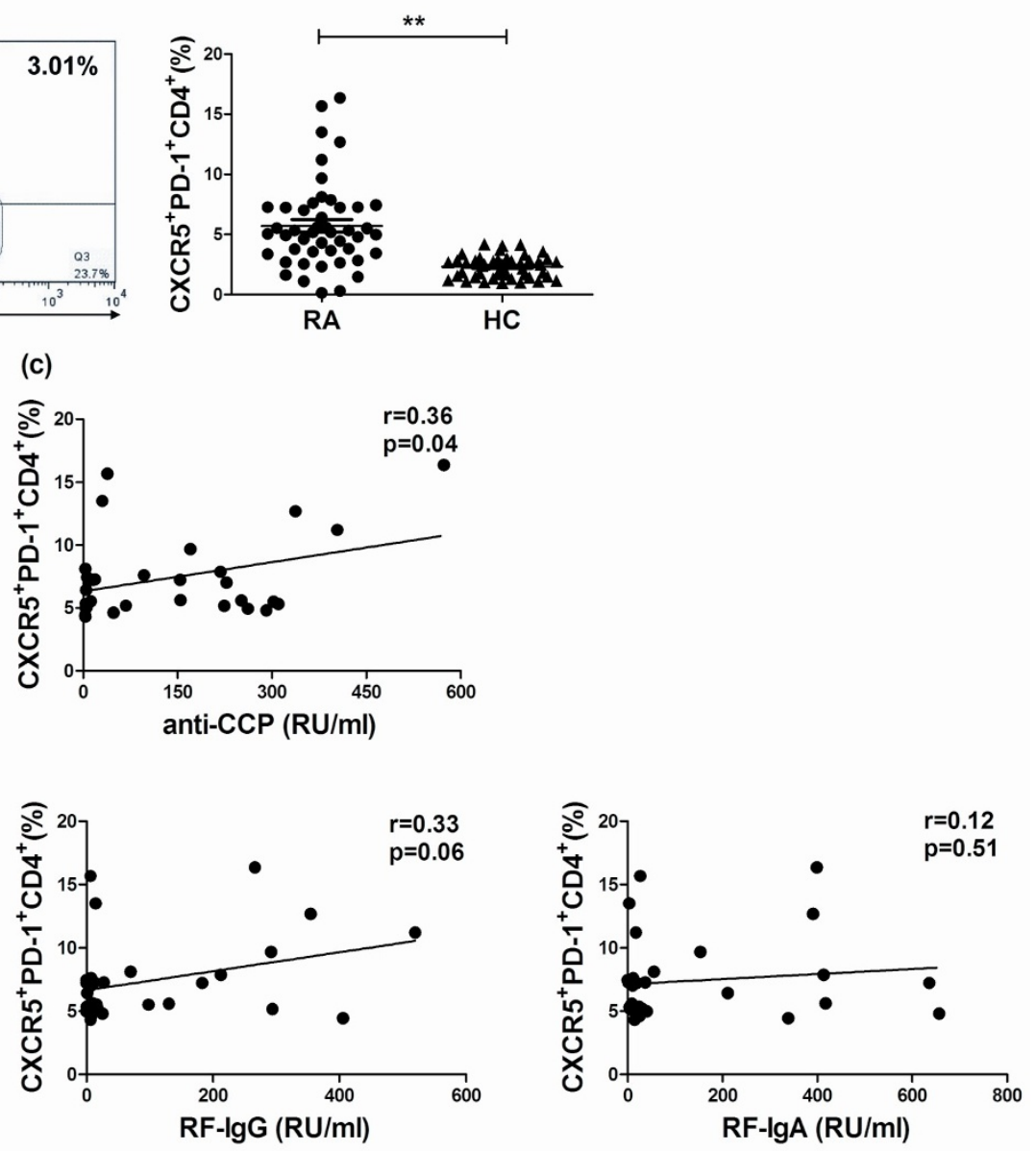

Figure 2 Positive correlation of increased T follicular helper (Tfh)-like cells with disease activity and auto-antibody production in patients with rheumatoid arthritis (RA). (a) Frequencies of circulating CXCR5 ${ }^{+} P D-1^{+} C D 4^{+}$Tfh-like cells were significantly higher in peripheral blood (PB) of RA patients $(n=47)$ than in healthy controls $(\mathrm{HC})(n=47)$. (b) There was positive correlation between Tfh-like cells and 28-joint count disease activity score (DAS28) in RA patients with high levels of Tfh-like cells $(n=31)$. (c) There was a positive correlation between Tfh-like cells and levels of anti-cyclic citrullinated peptide (anti-CCP antibody) in RA patients with high levels of Tfh-like cells $(n=31)$. (d) Tfh-like cells had no relationship with levels of rheumatoid factor (RF)-lgM, RF-lgG and RF-lgA in RA patients with high levels of Tfh-like cells $(n=31)$. ${ }^{*} P<0.01 ;{ }^{*} P<0.05$.

vs. $0.80 \% \pm 0.22 \%$ vs. $0.79 \% \pm 0.21 \%, P>0.05 ;$ CD 40 : $70.37 \% \pm 1.30 \%$ vs. $71.83 \% \pm 1.63 \%$ vs. $70.16 \% \pm 1.42 \%$, $P>0.05$; Figure 4d). Serum IL-21 levels in these subjects are shown in Additional file $2 \mathrm{~d}$. To further explore why IL-21 exposure was prone to activating B cells in RA, we performed microarray analysis of serum from RA patients. We found that several kinds of inflammatory factors were increased (Figure 4e), suggesting an inflammatory microenvironment in RA. Therefore, it indicates that under an inflammatory microenvironment in RA patients, IL-21 is sensitive to activation of B cells.

The impact of IL-21 on B cell proliferation and differentiation in RA patients

As previous reports suggested that IL-21 could co-stimulate mature B cells to proliferate in mice [32,33], we studied whether it could promote B cell proliferation in RA patients. Figure $5 \mathrm{a}$ demonstrates that in the presence of anti-CD40 and rIL-4, rIL-21 had more effect on B cell proliferation in RA, evidenced by dilution of CFSE. This effect was reversed by anti-IL-21R antibodies in both RA patients $(41.65 \% \pm 3.00 \%$ vs. $52.82 \% \pm 4.03 \%$ vs. $46.50 \% \pm 2.72 \%, P$ $<0.05$; Figure $5 \mathrm{a})$ and $\mathrm{HC}(28.87 \% \pm 3.66 \%$ vs. $38.12 \% \pm$ $2.66 \%$ vs. $33.13 \% \pm 3.59 \%, P<0.05$; Figure $5 a)$. Serum IL21 levels in these subjects are shown in Additional file 2e. Unexpectedly, IL-21 failed to influence B cell apoptosis in RA patients $(24.41 \% \pm 4.82 \%$ vs. $24.30 \% \pm 4.89 \%, P>0.05$; Figure $5 \mathrm{~b})$, whereas it was able to enhance $\mathrm{B}$ cell apoptosis in $\mathrm{HC}(10.21 \% \pm 1.06 \%$ vs. $15.37 \% \pm 2.29 \%, P<0.05$; Figure $5 b)$. These data indicate different effects of IL-21 on B cell apoptosis in RA patients and HC. Serum IL-21 levels in these subjects are shown in Additional file $2 \mathrm{f}$. 


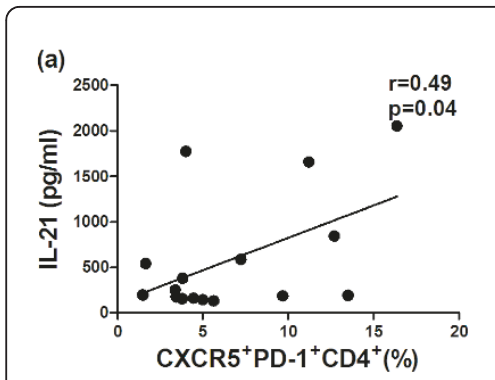

(b) Gated to $\mathrm{CD}^{+}$cells

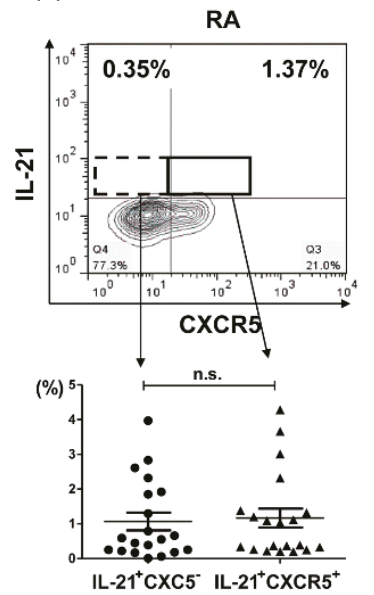

(e)

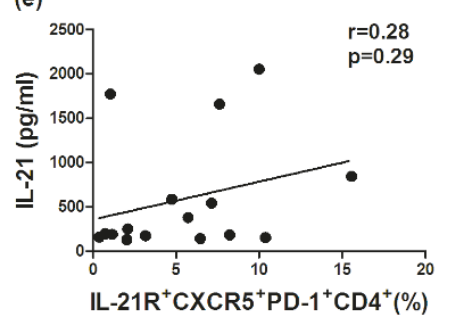

(c) Gated to $\mathrm{CD4}{ }^{+} \mathrm{CXCR} 5^{+}$cells
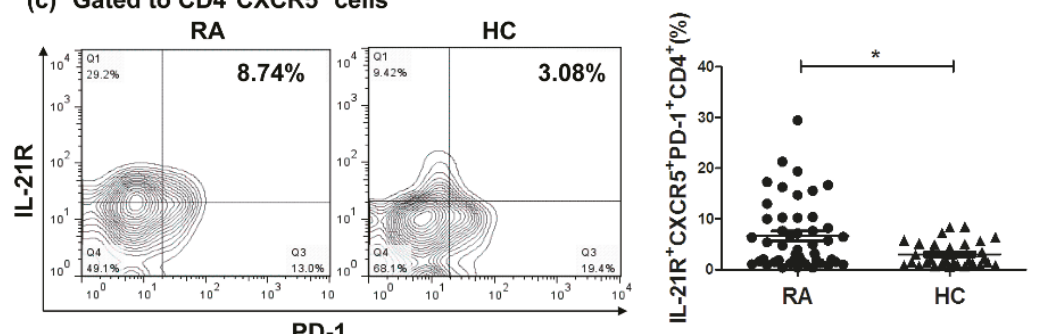

(d) Gated to $\mathrm{CD}^{+}$cells
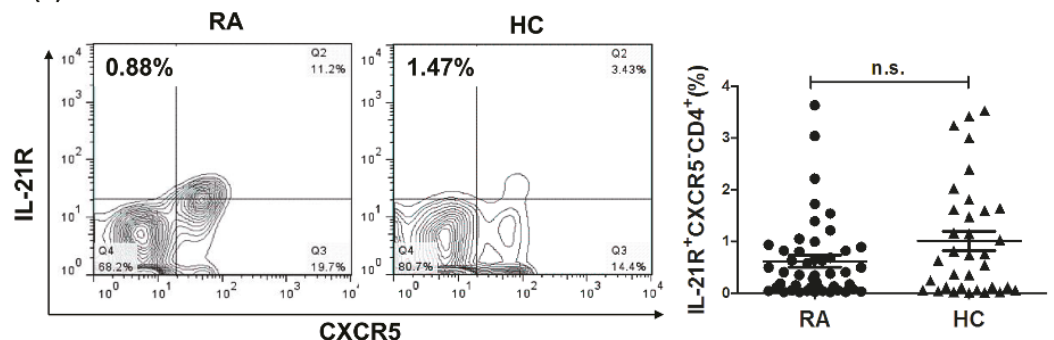

(f) Gated to $\mathrm{CD}^{+} \mathrm{CXCR}^{+}$cells

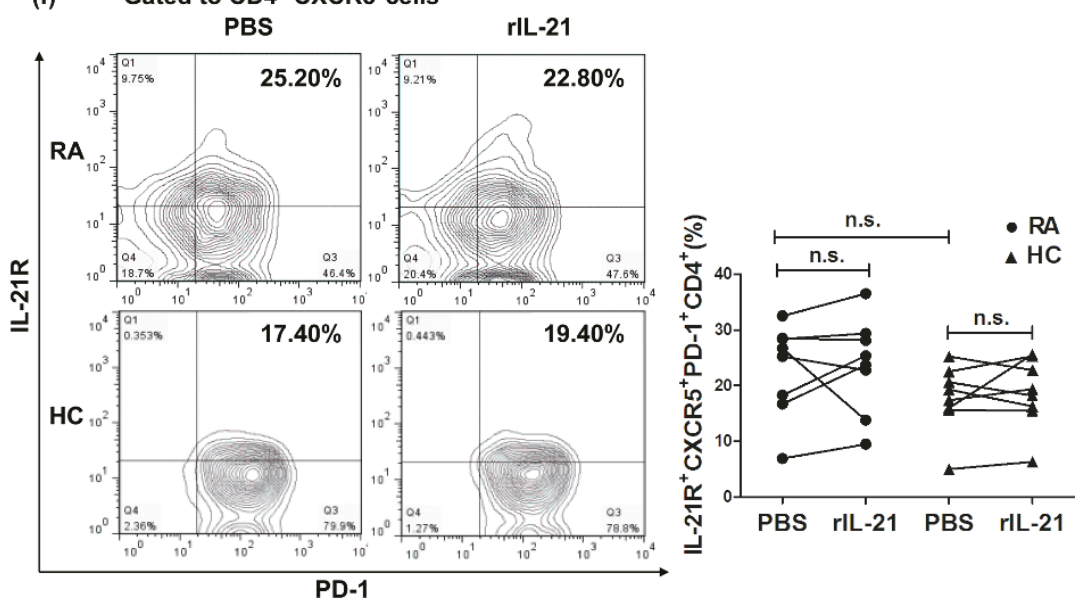

Figure 3 Positive correlation of increased serum IL-21 with circulating T follicular helper (Tfh)-like cells in patients with rheumatoid arthritis (RA). (a) Serum IL-21 positively correlated with the percentages of circulating Tfh-like cells in RA patients with high IL-21 ( $n=16)$. (b) IL-21 derived from both CXCR5 ${ }^{+} \mathrm{CD} 4^{+} \mathrm{T}$ cells and CXCR5 ${ }^{-} \mathrm{CD} 4^{+} \mathrm{T}$ cells in RA patients $(n=20)$. (c) IL-21R expression on Tfh-like cells in peripheral blood (PB) from RA patients $(n=47)$ was substantially upregulated compared to healthy controls $(H C)(n=34)$. (d) IL-21R expression on CXCR5 CD4 ${ }^{+} T$ cells was unchanged in RA patients. (e) IL-21 had no relationship with IL-21R expression on Tfh-like cells in RA patients with high IL-21 ( $n=16)$. (f) Peripheral blood mononuclear cells (PBMC) isolated from either RA patients $(n=8)$ or HC $(n=8)$ were cultured with $10 \mu \mathrm{g} / \mathrm{ml}$ phytohemagglutinin (PHA; Sigma) in the presence and absence of rlL-21 $(100 \mathrm{ng} / \mathrm{ml})$, and IL-21R expression on Tfh-like cells was analyzed after $48 \mathrm{~h} . * P<0.05$; n.S., not significant. PBS, phosphate-buffered saline.

As large amounts of RF and anti-CCP antibody appeared in the serum of RA patients, we next observed the effect of IL-21 on the production of IgG and IgM by B cells in RA patients and HC. We showed that rIL-21 upregulated the frequencies of plasmablasts $\left(\mathrm{CD} 138^{+} \mathrm{CD} 19^{\text {low/+ }}\right)$ both in RA patients $(7.30 \% \pm 1.01 \%$ vs. $9.24 \% \pm 1.08 \%, P<0.05$; Figure $5 \mathrm{c})$ and $\mathrm{HC}(3.26 \% \pm 0.66 \%$ vs. $4.12 \% \pm 0.93 \%, P<$ 0.05 ; Figure $5 \mathrm{c}$ ). However, IL-21-mediated B cell differentiation was stronger in RA patients than in HC. Furthermore, IL-21 induced B cells to produce higher levels of IgG and IgM in RA patients (IgG: $297.20 \pm 24.77$ vs. $353.70 \pm 29.30 \mathrm{ng} / \mathrm{ml}, P<0.05 ;$ IgM: $12.43 \pm 4.39$ vs. 20.47 $\pm 9.73 \mathrm{ng} / \mathrm{ml}, P>0.05$; Figure $5 \mathrm{~d}$ ) compared to $\mathrm{HC}$ (IgG: $221.60 \pm 18.19$ vs. $258.50 \pm 24.51 \mathrm{ng} / \mathrm{ml}, P<0.05$; IgM: $3.29 \pm 0.18$ vs. $3.03 \pm 0.19 \mathrm{ng} / \mathrm{ml}, P>0.05$; Figure $5 \mathrm{~d}$ ), although there were no marked differences in the secretion of IgM. Serum IL-21 levels in these subjects are shown in Additional file 2g.

\section{Discussion}

Previous studies have detected IL-21R at mRNA and protein levels in synovial tissue samples from RA patients $[28,34]$, supporting the idea that IL-21/IL-21R is implicated in the pathogenesis of RA. In the present 

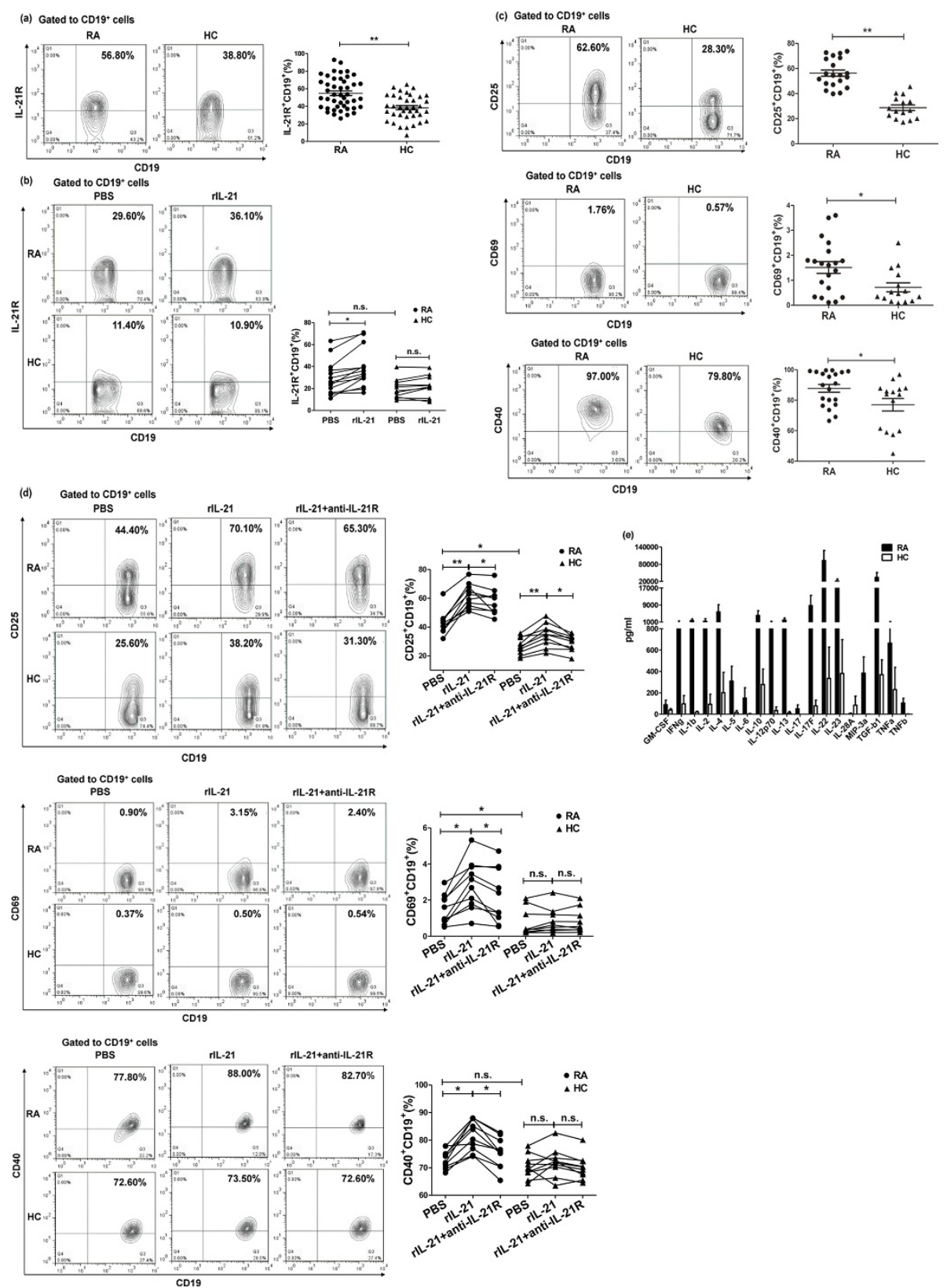

Figure 4 The effect of IL-21 on IL-21 receptor (R) of B cells and B cell activation in patients with rheumatoid arthritis (RA). (a) IL-21R expression on B cells was substantially upregulated in RA patients $(n=45)$ compared to healthy controls $(\mathrm{HC})(n=38)$. (b) Peripheral blood mononuclear cells (PBMC) from either RA patients $(n=14)$ or HC $(n=11)$ were cultured with or without rlL-21 $(100 \mathrm{ng} / \mathrm{ml})$, and IL-21R expression on B cells was analyzed after $48 \mathrm{~h}$. (c) Activation marker expressions on B cells were significantly upregulated in RA patients $(n=20)$ compared to HC $(n=15)$. (d) PBMC isolated from RA patients $(n=10)$ and HC $(n=10)$ were stimulated with rlL-21 $(100 \mathrm{ng} / \mathrm{ml})$ or rlL-21 in combination with anti-IL-21R antibody $(10 \mathrm{ug} / \mathrm{ml})$, and activation marker expressions on B cells were examined after $72 \mathrm{~h}$. (e) Microarray analysis of cytokines in serum from RA patients $(n=6)$ and HC $(n=4)$. ${ }^{*} P<0.01$; ${ }^{*} P<0.05$; n.S., not significant. PBS, phosphate-buffered saline.

study we showed serum IL-21 levels were significantly increased in RA patients. IL-21 concentrations were positively correlated with anti-CCP antibodies in the high IL-21 group of RA patients, suggesting IL-21 might be involved in auto-antibody production. Moreover, the high IL-21 levels were correlated with DAS28, indicating that IL-21 relates to clinical activity, which is consistent with the study by Rasmussen et al.[35].

$\mathrm{Tfh}$ cells are a subset of $\mathrm{T}$ cells that specialize in providing help for B cells. They are characterized by increased expression of molecules including CXCR5, PD-1, ICOS, CD40L and IL-21, and decreased expression of CCR7 [10]. 

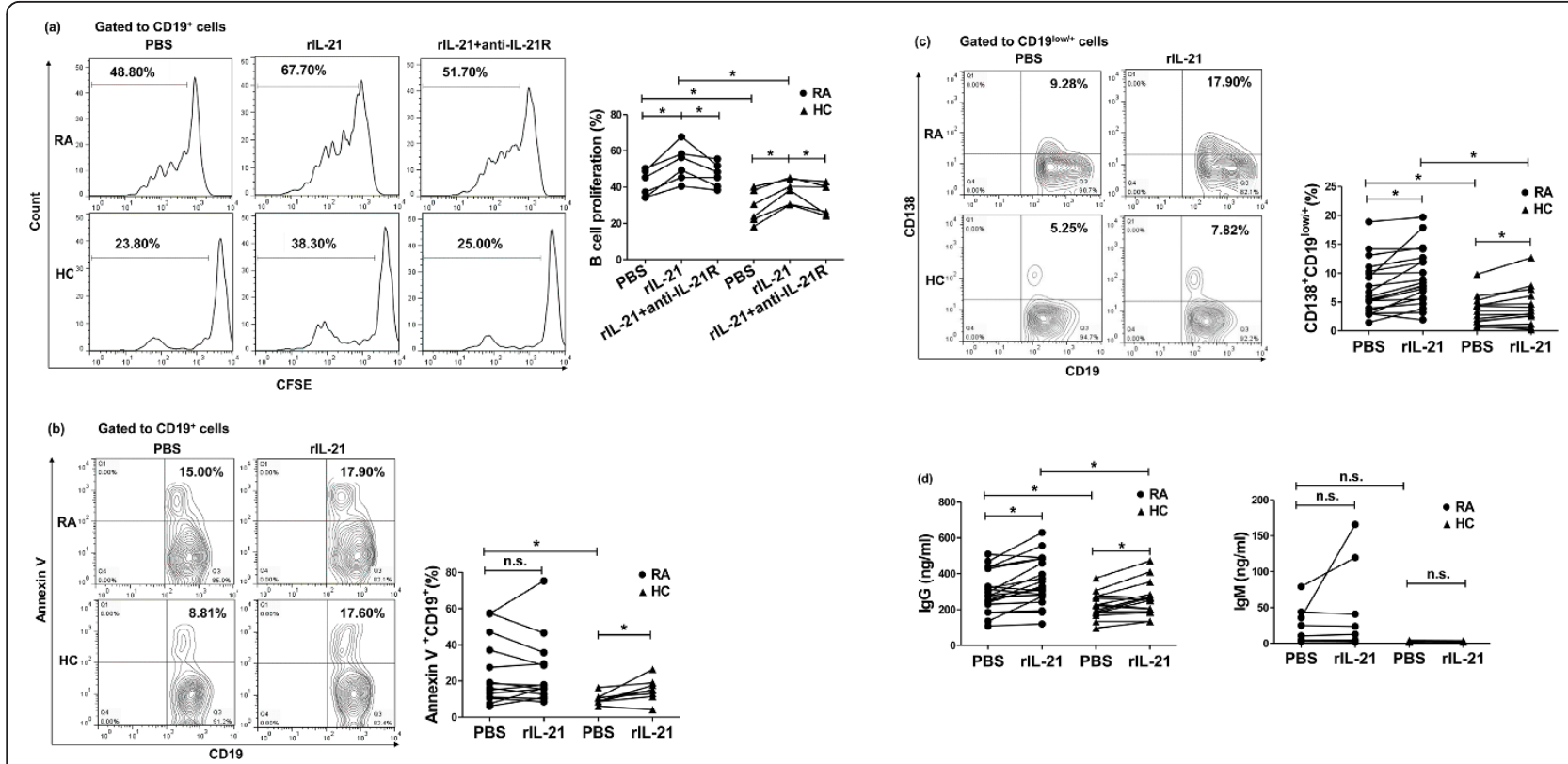

Figure 5 Impact of IL-21 on B cell proliferation and differentiation in patients with rheumatoid arthritis (RA). (a) Peripheral blood mononuclear cells (PBMC) isolated from RA patients $(n=6)$ and healthy controls $(\mathrm{HC})(n=6)$ were labeled with carboxyfluorescein diacetate succinimidyl ester (CFSE) and then stimulated with anti-CD40 $(3 \mu \mathrm{g} / \mathrm{ml})$ and $\mathrm{rlL}-4(50 \mathrm{ng} / \mathrm{ml})$ in the presence or absence of rlL-21 (100 ng/ml). After $96 \mathrm{~h}$ of culture, B cell proliferation was determined. (b) PBMC isolated from RA patients $(n=14)$ and HC $(n=8)$ stimulated with anti-CD40 $(3 \mu \mathrm{g} / \mathrm{ml})$ in the presence or absence of $\mathrm{rlL}-21(100 \mathrm{ng} / \mathrm{ml})$. Cells stained with Annexin V were examined after $72 \mathrm{~h}$. (c) PBMC isolated from RA patients $(n=20)$ and $\mathrm{HC}(n=15)$ were stimulated with a combination of anti-CD40 $(3 \mu \mathrm{g} / \mathrm{ml})$ and anti-lgM $(5 \mu \mathrm{g} / \mathrm{ml})$ in the presence or absence of rll-21 $(100 \mathrm{ng} / \mathrm{ml})$. After $96 \mathrm{~h}$, the frequencies of CD138 $8^{+} \mathrm{CD} 19^{\text {low/+ }}$ plasmablasts were determined. (d) Secretion of lgG and IgM in culture supernatant was assessed by ELISA *P $<0.05$; n.s., not significant. PBS, phosphate-buffered saline.

Most of the Tfh cells are located in the light zone of GC in secondary lymphoid tissue in human, but it was reported that human blood $\mathrm{CD} 4^{+} \mathrm{CXCR} 5^{+} \mathrm{T}$ cells also shared functional properties with Tfh cells [17]. In our study we observed that the frequencies of circulating Tfh-like cells markedly increased in PB from RA patients, suggesting Tfh-like cells might be involved in the pathogenesis of RA. As the function of Th cells was assisting B cells to secret antibodies, we next assessed the relationship between Tfhlike cells and anti-CCP antibodies/RF. The results revealed that the high percentages of Tfh-like cells were positively correlated with anti-CCP antibodies but not RF.

Based on the relationship between IL-21 and autoantibody production, we focused on the role of IL-21 in regulating Tfh-like cells and $B$ cells, two principal cells contributing to antibody secretion. First of all, we found that high IL-21 levels were positively correlated with the frequencies of Tfh-like cells. Furthermore, IL-21R expression on Tfh-like cells was upregulated, confirming that Tfh-like cells are potent responders for IL-21. Reportedly, IL-21 was essential for B cell activation [36] and was the most potent $\mathrm{T}$ cell-derived cytokine to induce $\mathrm{B}$ cell proliferation from PB, spleen, and tonsil in humans [11]. Our study demonstrated that IL-21 was able to directly promote B cell activation in vitro in RA patients. Moreover,
IL-21 induced B cell expansion more significantly in RA patients than in HC. A balance between the proliferation and apoptosis of immune cells is needed to maintain homeostasis of the immune system. In this study, IL-21 had different impacts on the apoptosis of B cells in RA patients and HC. In HC, IL-21 promoted B cell apoptosis. A previous study demonstrated that IL-21 stimulation of murine $\mathrm{B}$ cells led to a rapid decrease of anti-apoptotic protein $\mathrm{Bcl}-2$ and $\mathrm{Bcl}-\mathrm{X}_{\mathrm{L}}$ at mRNA and protein levels [37], which might be a possible mechanism of our result. However, we did not find the influence of IL-21 on B cell apoptosis in RA patients. Notably, our results have shown that IL-21 stimulation promoted B cell activation and expansion in RA. This discrepancy implicates that IL-21 might be prone to inducing $B$ cell activation and expansion instead of apoptosis in RA.

Ig production is a key component in B cell differentiation and the generation of protective humoral immune responses. Accumulated evidence suggests that IL-21 in combination with CD40L and/or anti-IgM is an inducer of plasma cell differentiation [11,38]. Moreover, IL-21 has also been shown to be a critical cytokine that stimulates IgG production compared to IL-2, IL-4 and IL-10 [11,38]. We found that IL-21 induced anti-CD40 and anti-IgM-stimulated B cells to differentiate into plasmablasts, and yielded 
higher levels of IgG and IgM in RA patients compared to $\mathrm{HC}$, although there were no significant differences in the secretion of IgM. It indicates that the responsibility of IL21 for Ig production may be stronger in RA patients. Through microarray analysis we found many inflammatory factors levels were upregulated in serum from RA patients, suggesting an inflammatory microenvironment in RA. Among these elevated cytokines, IL-2, IL-4, IL-6, IL-7 and IL-10 are all critical for B cell survival and differentiation [39-43]. We speculate that these cytokines might also play important roles in regulating $B$ cell function in RA, and under this inflammatory microenvironment, IL-21 is prone to inducing B cell activation, expansion and differentiation.

IL-21 has been implicated in autoimmunity disease via the IL-21R pathway. Jang et al. addressed the theory that IL-21R deficiency in the K/BxN mouse model of inflammatory arthritis was sufficient to protect it from arthritis [29]. Blocking the IL-21 pathway with IL-21R-Fc fusion protein has been shown to ameliorate the clinical and histologic signs of arthritis and dramatically reduce total IgG1 and inflammatory cytokines levels [44]. Similarly, IL-21R-deficient BXSB.B6-Yaa+/J mice presented none of the abnormal characteristics of systemic lupus erythematosus (SLE) in IL-21R-competent Yaa mice, including hypergammaglobulinemia, auto-antibody production and reduced frequencies of marginal zone B cells [45]. Blockade of IL-21 with IL-21R-Fc fusion protein has resulted in fewer IgG glomerular deposits, circulating dsDNA auto-antibodies, total sera IgG1, IgG2a and lymphadenopathy in the lupus-prone MRL-Fas ${ }^{\text {lpr }}$ mouse [46]. Corresponding to therapeutic efficacy, administration of IL-21R-Fc fusion protein to BXSB.B6-Yaa+/J mice, another model of lupus, decreased lymphocyte activation and circulating IgG1 levels [47]. In our study, IL-21 induced $\mathrm{B}$ cell activation and proliferation could be reversed by anti-IL-21R antibody, which may indicate that IL-21 regulates B cell function via binding with IL-21R.

\section{Conclusions}

Our results highlight that increased serum IL-21 levels in RA patients correlate with serum DAS28, anti-CCP antibody and the frequencies of Tfh-like cells. IL-21 supports $B$ cell activation, proliferation and antibody secretion via the IL-21R pathway. All these data indicate IL-21 is involved in the pathogenesis of RA. Therefore, it opens avenues for the possibility that IL-21 might be targeted by therapeutic strategies for the clinical management of RA in the future.

\section{Additional material}

Additional file 1: (a) The serum levels of IL-21 in Figure 2a. (b) The serum levels of IL-21 in Figure 3c. (c) The serum levels of IL-21 in Figure 3f.
Additional file 2: (a) The serum levels of IL-21 in Figure 4a. (b) The serum levels of IL-21 in Figure 4b. (c) The serum levels of IL-21 in Figure 4c. (d) The serum levels of IL-21 in Figure 4d. (e) The serum levels of IL-21 in Figure 5a. (f) The serum levels of IL-21 in Figure 5b. (g) The serum levels of IL-21 in Figure 5c.

\section{Abbreviations}

anti-CCP: anti-cyclic citrullinated peptide; APC: allophycocyanin; CFSE: carboxyfluorescein diacetate succinimidyl ester; CRP: C-reactive protein; CS: corticosteroid; DAS28: 28-joint count disease activity score; DMARDs: diseasemodifying antirheumatic drugs; ELISA: enzyme-linked immunosorbent assay; ESR: erythrocyte sedimentation; FCS: fetal calf serum; FITC: fluorescein isothiocyanate; GC: germinal centre; HC: healthy control; Ig: immunoglobulin; IL-21: interleukin-21; IL-21R: interleukin-21 receptor; NK: natural killer; NSAIDs: non-steroidal anti-inflammatory drugs; OA: osteoarthritis; PB: peripheral blood; PBMC: peripheral blood mononuclear cells; PBS: phosphate-buffered saline; PC: plasma cell; PE: phycoerythrin; PHA: phytohemagglutinin RA: rheumatoid arthritis; RF: rheumatoid factor; SEM: standard error of the mean; Tfh: T follicular helper.

\section{Acknowledgements}

This work was funded by the National Natural Science Foundation of China (No. 81172847, 30972736); Jiangsu Province Natural Science Foundation (BK2009034); Major International (Regional) Joint Research Project (81120108021), Jiangsu Province Kejiao Xingwei Program and National Basic Research Program of China (Grant No. 2010 CB 529100); Nanjing Young Medical Talent Project; China Postdoctoral Science Foundation the First Class (2012M510073), and the Intramural Research Program of the National Institutes of Health, NIDCR.

\section{Author details}

${ }^{1}$ Department of Immunology and Rheumatology, Drum Tower Clinical Medical College of Nanjing Medical University, Nanjing, Jiangsu, 210008, PR China. ${ }^{2}$ Department of Immunology and Rheumatology, The Affiliated Drum Tower Hospital of Nanjing University Medical School, Nanjing, Jiangsu, 210008, PR China. ${ }^{3}$ Mucosal Immunology Section, National Institute of Dental and Craniofacial Research, National Institutes of Health, Bethesda, Maryland, USA. ${ }^{4}$ Department of Biochemistry, Dalian Medical University, Dalian, Liaoning, 116044, PR China.

\section{Authors' contributions}

$\mathrm{XL}$ and LYS designed and directed the research. $\mathrm{RL}$ performed the experiments, analyzed and interpreted data and drafted the manuscript. QW, DLS and LYG collected the data. WJC, NC, HFC, and JYC provided critical input and edited the manuscript. All authors read and approved the final manuscript for publication.

\section{Competing interests}

The authors declare that they have no competing interests.

Received: 14 June 2012 Revised: 23 July 2012

Accepted: 21 November 2012 Published: 23 November 2012

\section{References}

1. Spolski R, Leonard WJ: Interleukin-21: Basic biology and implications for cancer and autoimmunity. Annu Rev Immunol 2008, 26:57-79.

2. Ozaki K, Kikly K, Michalovich D, Young PR, Leonard WJ: Cloning of a type I cytokine receptor most related to the IL-2 receptor beta chain. Proc Natl Acad Sci USA 2000, 97:11439-11444.

3. Asao H, Okuyama C, Kumaki S, Ishii N, Tsuchiya S, Foster D, Sugamura K: Cutting edge: The common gamma-chain is an indispensable subunit of the IL-21 receptor complex. J Immunol 2001, 167:1-5.

4. Leonard WJ: Cytokines and immunodeficiency diseases. Nat Rev Immunol 2001, 1:200-208.

5. Strengeil M, Sareneva T, Foster D, Julkunen I, Matikainen S: IL-21 upregulates the expression of genes associated with innate immunity and Th1 response. J Immunol 2002, 169:3600-3605. 
6. Terrier B, Geri G, Chaara W, Allenbach Y, Rosenzwajg M, CostedoatChalumeau N, Fouret P, Musset L, Benveniste O, Six A, Klatzmann D, Saadoun D, Cacoub P: Interleukin-21 modulates Th1 and Th17 responses in giant cell arteritis. Arthritis Rheum 2012, 64:2001-2011.

7. Monteleone G, Pallone F, MacDonald TT: Interleukin-21: a critical regulator of the balance between effector and regulatory T-cell responses. Trends Immunol 2008, 29:290-294.

8. Spolski R, Leonard WJ: The Yin and Yang of interleukin-21 in allergy, autoimmunity and cancer. Curr Op Immunol 2008, 20:295-301.

9. Linterman MA, Beaton L, Yu D, Ramiscal RR, Srivastava M, Hogan JJ, Verma NK, Smyth MJ, Rigby RJ, Vinuesa CG: IL-21 acts directly on B cells to regulate $\mathrm{BCl}-6$ expression and germinal center responses. J Exp Med 2010, 207:353-363.

10. King C, Tangye SG, Mackay CR: $T$ follicular helper (T(FH)) cells in normal and dysregulated immune responses. Ann Rev Immunol 2008, 26:741-766.

11. Ettinger R, Sims GP, Fairhurst AM, Robbins R, da Silva YS, Spolski R, Leonard WJ, Lipsky PE: IL-21 induces differentiation of human naive and memory B cells into antibody-secreting plasma cells. J Immunol 2005, 175:7867-7879.

12. Good KL, Bryant VL, Tangye SG: Kinetics of human B cell behavior and amplification of proliferative responses following stimulation with IL-21. J Immunol 2006, 177:5236-5247.

13. Pene J, Gauchat JF, Lecart S, Drouet E, Guglielmi P, Boulay V, Delwail A, Foster D, Lecron JC, Yssel H: Cutting edge: IL-21 is a switch factor for the production of $\lg \mathrm{G}(1)$ and $\operatorname{lgG}(3)$ by human B cells. J Immunol 2004, 172:5154-5157.

14. Nurieva Rl, Chung $Y$, Hwang $D$, Yang $X O$, Kang HS, Ma L, Wang $Y H$, Watowich SS, Jetten AM, Tian Q, Dong C: Generation of T follicular helper cells is mediated by interleukin-21 but independent of $T$ helper 1, 2, or 17 cell lineages. Immunity 2008, 29:138-149.

15. Vogelzang A, McGuire HM, Yu D, Sprent J, Mackay CR, King C: A fundamental role for interleukin-21 in the generation of $\mathrm{T}$ follicular helper cells. Immunity 2008, 29:127-137.

16. Bryant VL, Ma CS, Avery DT, Li Y, Good KL, Corcoran LM, Malefyt RD, Tangye SG: Cytokine-mediated regulation of human B cell differentiation into Ig-secreting cells: Predominant role of IL-21 produced by CXCR5(+) T follicular helper cells. J Immunol 2007, 179:8180-8190.

17. Morita R, Schmitt N, Bentebibel SE, Ranganathan R, Bourdery L, Zurawski G, Foucat E, Dullaers M, Oh S, Sabzghabaei N, Lavecchio EM, Punaro M, Pascual V, Banchereau J, Ueno H: Human blood CXCR5(+)CD4(+) T cells are counterparts of $\mathrm{T}$ follicular cells and contain specific subsets that differentially support antibody secretion. Immunity 2011, 34:108-121.

18. Kashiwakuma D, Suto A, Hiramatsu Y, Ikeda K, Takatori H, Suzuki K, Kagami S, Hirose K, Watanabe N, Iwamoto I, Nakajima H: B and T lymphocyte attenuator suppresses IL-21 production from follicular Th cells and subsequent humoral immune responses. J Immunol 2010, 185:2730-2736.

19. Rankin AL, MacLeod H, Keegan S, Andreyeva T, Lowe L, Bloom L, Collins M, Nickerson-Nutter C, Young D, Guay H: IL-21 Receptor is critical for the development of memory B cell responses. J Immunol 2011, 186:667-674.

20. Zotos D, Coquet JM, Zhang Y, Light A, D'Costa K, Kallies A, Corcoran LM, Godfrey DI, Toellner KM, Smyth MJ, Nutt SL, Tarlinton DM: IL-21 regulates germinal center $\mathrm{B}$ cell differentiation and proliferation through a B cellintrinsic mechanism. J Exp Med 2010, 207:365-378.

21. Salaffi F, Carotti M, Ciapetti A, Gasparini S, Filippucci E, Grassi W: Relationship between time-integrated disease activity estimated by DAS28-CRP and radiographic progression of anatomical damage in patients with early rheumatoid arthritis. BMC Musculoskelet Disord 2011, 12:120.

22. Vittecoq O, Pouplin S, Krzanowska K, Jouen-Beades F, Menard JF, Gayet A, Daragon A, Tron F, Le Loet X: Rheumatoid factor is the strongest predictor of radiological progression of rheumatoid arthritis in a threeyear prospective study in community-recruited patients. Rheumatology 2003, 42:939-946.

23. Miriovsky BJ, Michaud K, Thiele GM, O'Dell JR, Cannon GW, Kerr G, Richards JS, Johnson D, Caplan L, Reimold A, Hooker R, Mikuls TR: Anti-CCP antibody and rheumatoid factor concentrations predict greater disease activity in men with rheumatoid arthritis. Ann Rheum Dis 2010, 69:1292-1297.

24. Vander Cruyssen B, Hoffman IEA, Peene I, Union A, Mielants H, Meheus L, De Keyser F: Prediction models for rheumatoid arthritis during diagnostic investigation: evaluation of combinations of rheumatoid factor, anti- citrullinated protein/peptide antibodies and the human leucocyte antigen-shared epitope. Ann Rheum Dis 2007, 66:364-369.

25. Ding B, Padyukov L, Lundstrom E, Seielstad M, Plenge RM, Oksenberg JR, Gregersen PK, Alfredsson L, Klareskog L: Different patterns of associations with anti-citrullinated protein antibody-positive and anti-citrullinated protein antibody-negative rheumatoid arthritis in the extended major histocompatibility complex region. Arthritis Rheum 2009, 60:30-38.

26. Kuhn KA, Kulik L, Tomooka B, Braschler KJ, Arend WP, Robinson WH, Holers VM: Antibodies against citrullinated proteins enhance tissue injury in experimental autoimmune arthritis. J Clin Invest 2006, 116:961-973.

27. Petkova SB, Konstantinov KN, Sproule TJ, Lyons BL, Al Awwami M, Roopenian DC: Human antibodies induce arthritis in mice deficient in the low-affinity inhibitory IgG receptor Fc gamma RIIB. J Exp Med 2006, 203:275-280

28. Jungel A, Distler JHW, Kurowska-Stolarska M, Seemayer CA, Seibl R, Forster A, Michel BA, Gay RE, Emmrich F, Gay S, Distler O: Expression of interleukin-21 receptor, but not interleukin-21, in synovial fibroblasts and synovial macrophages of patients with rheumatoid arthritis. Arthritis Rheum 2004, 50:1468-1476.

29. Jang E, Cho SH, Park H, Paik DJ, Kim JM, Youn J: A positive feedback loop of IL-21 signaling provoked by homeostatic CD4(+)CD25(-) T cell expansion is essential for the development of arthritis in autoimmune K/BxN mice. J Immunol 2009, 182:4649-4656.

30. Prevoo MLL, Vanthof MA, Kuper HH, Vanleeuwen MA, Vandeputte LBA, Vanriel P: Modified disease-activity scores that include 28-joint countsdevelopment and validation in a prospective longitudinal-study of patients with rheumatoid-arthritis. Arthritis Rheum 1995, 38:44-48.

31. Fazilleau N, Mark L, McHeyzer-Williams LJ, McHeyzer-Williams MG: Follicular helper T cells: lineage and location. Immunity 2009, 30:324-335.

32. Jin HL, Carrio R, Yu AX, Malek TR: Distinct activation signals determine whether IL-21 induces B cell costimulation, growth arrest, or bimdependent apoptosis. J Immunol 2004, 173:657-665.

33. Ozaki K, Spolski R, Ettinger R, Kim HP, Wang G, Qi CF, Hwu P, Shaffer DJ, Akilesh S, Roopenian DC, Morse HC, Lipsky PE, Leonard WJ: Regulation of B cell differentiation and plasma cell generation by IL-21, a novel inducer of blimp-1 and bcl-61. J Immunol 2004, 173:5361-5371.

34. Li J, Shen W, Kong K, Liu Z: Interleukin-21 induces T-cell activation and proinflammatory cytokine secretion in rheumatoid arthritis. Scand J Immunol 2006, 64:515-522.

35. Rasmussen TK, Andersen T, Hvid M, Hetland ML, Horslev-Petersen K, Stengaard-Pedersen K, Holm CK, Deleuran B: Increased Interleukin 21 (IL21) and IL-23 are associated with increased disease activity and with radiographic status in patients with early rheumatoid arthritis. J Rheumatol 2010, 37:2014-2020.

36. Kuchen S, Robbins R, Sims GP, Sheng C, Phillips TM, Lipsky PE, Ettinger R: Essential role of IL-21 in B cell activation, expansion, and plasma cell generation during CD4(+) T cell-B cell collaboration. J Immunol 2007, 179:5886-5896

37. Mehta DS, Wurster AL, Whitters MJ, Young DA, Collins M, Grusby MJ: IL-21 induces the apoptosis of resting and activated primary B cells. $\mathrm{J}$ Immunol 2003, 170:4111-4118.

38. Avery DT, Deenick EK, Ma CS, Suryani S, Simpson N, Chew GY, Chan TD, Palendira U, Bustamante J, Boisson-Dupuis S, Choo S, Bleasel KE, Peake J, King C, French MA, Engelhard D, Al-Hajjar S, Al-Muhsen S, Magdorf K, Roesler J, Arkwright PD, Hissaria P, Riminton DS, Wong M, Brink R, Fulcher DA, Casanova JL, Cook MC, Tangye SG: B cell-intrinsic signaling through IL-21 receptor and STAT3 is required for establishing long-lived antibody responses in humans. J Exp Med 2010, 207:155-171.

39. Matek TR: The biology of interleukin-2. Ann Rev Immunol 2008, 26:453-479.

40. Kuhn R, Rajewsky K, Muller W: Generation and analysis of interleukin-4 deficient mice. Science 1991, 254:707-710.

41. Hirano T, Yasukawa K, Harada H, Taga T, Watanabe Y, Matsuda T, Kashiwamura S, Nakajima K, Koyama K, Iwamatsu A, Tsunasawa S, Sakiyama F, Matsui H, Takahara Y, Taniguchi T, Kishimoto T: Complementary-DNA for a novel human interleukin (BSF-2) that induces lymphocytes-B to produce immunoglobulin. Nature 1986, 324:73-76.

42. Vonfreedenjeffry U, Vieira P, Lucian LA, McNeil T, Burdach SEG, Murray R: Lymphopenia in interleukin (IL)-7 gene-deleted mice identifies IL-7 as a nonredundant cytokine. J Exp Med 1995, 181:1519-1526.

43. Akdis CA, Akdis M: Mechanisms and treatment of allergic disease in the big picture of regulatory T cells. J Allergy Clin Immunol 2009, 123:735-746. 
44. Young DA, Hegen M, Ma HLM, Whitters MJ, Albert LM, Lowe L, Senices $M$, Wu PW, Sibley B, Leathurby Y, Brown TP, Nickerson-Nutter C, Keith JC Jr, Collins M: Blockade of the interleukin-21/interleukin-21 receptor pathway ameliorates disease in animal models of rheumatoid arthritis. Arthritis Rheum 2007, 56:1152-1163.

45. Bubier JA, Sproule TJ, Foreman O, Spolski R, Shaffer DJ, Morse HC, Leonard WJ, Roopenian DC: A critical role for IL-21 receptor signaling in the pathogenesis of systemic lupus erythematosus in BXSB-Yaa mice. Proc Natl Acad Sci USA 2009, 106:1518-1523.

46. Herber D, Brown TP, Liang S, Young DA, Collins M, DunussiJoannopoulos K: IL-21 has a pathogenic role in a lupus-prone mouse model and its blockade with IL-21R.Fc reduces disease progression. J Immunol 2007, 178:3822-3830

47. Bubier JA, Bennett SM, Sproule TJ, Lyons BL, Olland S, Young DA, Roopenian DC: Treatment of BXSB-Yaa mice with IL-21R-Fc fusion protein minimally attenuates systemic lupus erythematosus. Autoimmunity, Pt B: Novel Applications of Basic Research 2007, 1110:590-601.

doi:10.1186/ar4100

Cite this article as: Liu et al: A regulatory effect of IL-21 on T follicular helper-like cell and B cell in rheumatoid arthritis. Arthritis Research \&

Therapy 2012 14:R255.

\section{Submit your next manuscript to BioMed Central} and take full advantage of:

- Convenient online submission

- Thorough peer review

- No space constraints or color figure charges

- Immediate publication on acceptance

- Inclusion in PubMed, CAS, Scopus and Google Scholar

- Research which is freely available for redistribution

Submit your manuscript at www.biomedcentral.com/submit 